金原粲*1

\title{
Gleanings from My Research on Vacuum and Thin Films 20
}

Akira KINBARA*1

${ }^{* 1}$ Institute of Industrial Science, The University of Tokyo

(Received March 27, 2012, Accepted May 15, 2012)

\section{2 宇宙人? 出現}

私の世代は計算方法の激変をまともに受けた世代である. 国民学校（今の小学校）では，九九を暗誦させられた後，四 則演算の計算で算盤を習った。 もちろんそれがデジタル計算 機だなどとは考えたこともなかった．旧制中学で対数を習っ た後に竹でできたヘンミの計算尺というものを買わされ，掛 け算が足し算になる不思議を味わったが，これが算盤とは違 うアナログ計算機だとは思いもしなかった．大学に入ってタ イガー計算機を使った. 地球物理学の泰斗であった坪井忠二 先生から, 計算機の据え付け方まで教えてもらった. 四則演 算の計算には確かに便利であったが，音がうるさかった．大 学から大学院にかけて, 四則演算ができる, 今のパソコンく らいの大きさの卓上計算機が飛躍的に普及し, さらに関数電 卓が普及するとともに小型化が進んだ．その辺までは私も世 の中の最後尾にヨチヨチながらついていたような気がする. そして大型計算機とパソコンの出現とともに世の中から急速 に取り残されることになった.

大学に勤めて自分の居室にいるようになり，学生たちとの 交流が減ると, IT 事情に疎くなり, 彼等の計算能力があっ という間に私などどう頑張っても追いつかないくらいの速さ で向上してしまったことに気が付いた．物理を専攻している はずの彼等がどうしてあんなにコンピューターに習熟できる のかミステリーに思える.

研究室で遭遇したコンピューター通は多いし, すべての学 生みんなが私から見れば通に思えたが，特に際立って見えた のが松田七美男さん（現東京電機大学教授）である. 当時の 感じから言えば，世間離れした宇宙人のようなところがあっ た. 実験をこつこつやり, 薄膜の内部摩擦など力学的性質を 調べていた，そのうち蒸着で作られたカーボン薄膜が示した 強い圧縮性の内部応力に関心を集めてきた，そしてその圧縮 応力のため, 薄膜が基板上でバックリング (buckling) を起 こして㱀のように持ち上がる現象を仔細に調べ始めた。この 機械工学でいう挫屈現象は, フックの法則しか習ったことの なかった私にとって現象そのものがミステリーであった。松 田さんは㱀を上から見たり，断面の写真を撮ってみたりしな がら皺の形を決め, 㱀にたまった弾性エネルギーを計算し て, それを付着エネルギーの変換とみなし, そこから, 薄膜

\footnotetext{
*1 東京大学生産技術研究所 ( $7153-8505$ 東京都目黒区駒場 4-6-1
} TEL/FAX 03-5452-6131 e-mail: kinbara@iis.u-tokyo.ac.jp)
の基板に対する付着エネルギーを求めた. 㱀の形は複雑で, 数値計算以外解析は無理だと思っていたが，その数值計算も 当時の計算機の性能から見るとかなり面倒であったはずであ る.しかし，松田さんにとっては，あまり面倒なことでもな かったらしく，さほど苦労したように見えなかった．この結 果は

N. Matuda, S. Baba and A. Kinbara: Thin Solid Films, 81 (1981) 301

に発表されている. 薄膜のバックリングの研究例は少ない, さらに付着をエネルギー的に考察した例もほとんどなく, 意 外に反響があり，薄膜の付着の評価に役立った，彼は，今は むしろ真空科学との関わりが強く, 分子流のコンダクタンス 計算などで能力を発揮しているが，日本真空学会事務局の IT 化にも貢献したと聞いている，とれも十分にありうるこ とだろうと想像している.

もう一人の宇宙人は, 現在「J. Vac. Soc. Jpn」の編集副委 員長をしている中野武雄さん (現成蹊大学理工学部)である. 彼は私の東大に打ける最後の院生であったから，松田さんよ りはずっと若く, その分, 知識も手法も進んでいたと思う. 私は，モンテカルロだのシミュレーションだのと言われる 々, 当時は多少のいかがわしさを感じていたものだが，研究 室で初めて本格的なシミュレーション技法で $\mathrm{LaB}_{6}$ ターゲッ トからのスパッタリング原子の飛跡を追いかけた．実験，計 算対象に質量の大きく異なる 2 つの物質からなる化合物を 選んだことも幸いしたと思うが，驚くほど直観とも実験とも 整合性のよい結果を出してくれた．彼の宇宙人振りは松田さ ん以上であるが，物理を忘れていないおかげで私でも理解で きる成果を挙げている.

彼らは, 仕事はよくできるし, 研究成果を物理の言葉で書 いているのがうれしい. よく見ると 2 人とも地球人とは少 し違う顔をしているように見えて面白い.

\section{3 近頃の若いもの}

私が若い頃は多くの若者が恩師，先輩にあたる方々から， 生活習慣から研究の仕方全般にわたって, かなり頻繁に「近 頃の若いものは」という枕詞で始まる, 非難がましい批判 や, さらには悪口雑言, 罵睘謉謗を浴びせられたものであ る.そうはいっても，とにかく昔の人はいろいろのことをよ く知っていて，私は学ぶことも多かった.

大学院で一通り専門の基礎を詰め込まれれば一人前のはず 
である。しかし私自身に関していえば，半人前どころか， 1/10人前にもならなかったような気がする，大学院を終わ ってからの方が学んだことがはるかに多い。それは系統的な ものではなく, 場当たり的なもので, 多くは教室でなく, 現 場で“老”の付きそうな先生や先輩から仕入れたといえるも のであったが，蓄積されると膨大で有用であった，だから， 年寄りに対しては反発しながらも少なからず敬意を払ってき た.しかし, 自分が年寄りになった今, 後輩や若手に教える ことが少なくなってきた.

その最大の理由は, 自分の浅学非才は棚にあげることにし て，集積回路，もとをただせばトランジスターの発明にある と思っている。これらの発明の扔かげでコンピューターが普 及し, IT 革命が抢こり, 指数関数的に急速な情報伝達, 情 報拡大が起こった．その結果，年寄りの知識が急速に陳腐化 し，若者たちに教えるどころか，若者から教えてもらわなけ ればならないことが膨大になり, 先にあげた松田さんや中野 さんの時にもそうだったが, 年寄り, 若者の地位が逆転して しまったのである. 火打ち石で火を抗すに類するような技 術を若い人に伝える必要はなくなり, 特別な好事家を除けば 古い知識の習得に興味を示すものが少なく，それがなくても 大して困らないという世の中が到来した.

パソコンの普及と共に私もヨチヨチしながら何とかメール を送ったり原稿を書いたり講演用のスライドを作ったりする ことぐらいはしているが，一旦トラブルが発生すると完全に お手上げである，そのときマニュアルを見たり，メーカーに 聞いたりすることはない。見たり聞いたりしても説明にある 専門用語の意味が良く分からないからである. その場合, 近 くにいる「近頃の若いもの」に聞くと，たちどころに解決し てくれる. 今, もっとも近くにいて世話になっている「近頃 の若いもの」は編集委員である東大の松本益明さんで, 今書 いている原稿の電子投稿の仕方をはじめ, もろもろを松本さ んに教えてもらった. パソコンのトラブルに関しても松本さ んに执ぶにだっこである、世話になるばかりで，私の方か ら抢返しできる知識の持ち合わせなどないに等しい。「近頃 の若いもの」の持っている情報処理の速さにも感心する. 物 理現象とか物性定数とかを聞いてみると私の顔も見ずに，さ っとパソコンや携帯電話を眺めて教えてくれる. どこか知ら ない土地で場所探しをするときも，すぐに GPS で現在位置 と目標地点を見つけ出す。だから私は, 昔の先輩たちと異な り，まれに若者に「近頃の・..」の枕詞をつけることはあ っても，「スゲエ」と驚嘆するときである.

ただ，あえていやみを言わせてもらうと，彼らの知識はパ ソコンという篂笥の引き出しの中にあって，必ずしも彼らの 頭の中にあるとは言えない気がすることがある。そしてあら ゆる仕事に共通するコツといわれるものは，たぶんパソコン では探せず，老のつく先輩に聞く方が早い，そういうコツに 類する技術の伝承が年寄りの存在理由のように思える.

一：少しのことにも，先達はあらまほしき事なり。：一

: 吉田兼好 :

\section{4 老兵は死なず $\ldots$}

一:こころより我にはたらく仕事あれ
それを仕遂げて死なむと思子：一

: 石川啄木 :

若いころは一生の間に少なくとも一つ，後世に残るような 仕事をしたいものだと思っていたが，“仕遂げる”ことが容 易ではないと悟ったのは，定年を迎えるころで，手遅れにな ってからである，啄木は本気で“...仕遂げて死なむ．...” などと思ったのだろうか.

急に話が飛ぶようだが，私が知っている古今東西の有名人 の数は多くない，とくにアメリカ人となると，すぐに浮かぶ 名前は, ワシントン, エジソンくらいである.アインシュタ インは何国人というべきかよくわからない.ショックレイや ファインマンとなると, 有名人というには一般性に乏しい. そんな中で私にとって忘れがたい名前の一つがマッカーサー である。

若い人達にとって，この名前は遠い歴史上の人物か，まっ たく聞いたこともない名前になりつつあるかもしれないが， 私の中学・高校時代, 日本の実質的な支配者であったので, 強く印象に残っている．彼は，1945年日本がアメリカとの 戦争で敗北した後, 日本に進駐してきた占領軍の最高司令官 である。

色々の毀誉襄貶はあるが，私から見て “毀”，“貶”に当た る行為は, 日本人にとって至宝と言える仁科芳雄, 菊地正士 などの大先達が苦労の末に作り上げた, 理研, 阪大, 京大の サイクロトロンを, 占領軍として着任するや否や破壊したこ とである. 東京大空襲や広島, 長崎の原爆投下など不必要な 殺䵧にも彼の関与があるはずだが，彼が戦時下の軍人であっ たことを考えると, 彼一人の仕業というわけにはいかない.

しかし, 戦争終結後に, 残存すれば歴史的文化遺産になった かもしれない仁科のサイクロトロンを破壊した行為はどうあ っても許しがたいように思えるのである.

そういう彼の言行を取り上げるのにためらいはあるが，有 名なのがいくつか浮かんでくる. 日米開戦当時フィリピンに いて，日本軍に追われオーストラリアに逃亡する時の捨て台 詞 “I shall return”, 日本占領時代，アメリカの議会で日本 人に関する感想を聞かれた時の “日本人は 12 歳”など今で も覚えている. そして, 朝鮮戦争で中国空爆を主張して大統 領のトルーマンから最高司令官を解任され，日本からの帰国 後の米議会聴聞会で最後に述べた科白,

“Old soldiers never die ; they just fade away"

(老兵は死なず，消えゆくのみ)

がもっともよく知られている.

一時は大統領候補に擬せられたこともあったくらいだか ら, 政治的野心もあったのだろうが，その希望を断たれ，こ のような心境になったのであろう. 大きな仕事を成し遂げ， 満足しながらこの世を去るのは選ばれた人たちで, 大した成 果もあげずに平均寿命に到達しかかった私のような人間の, 人生の終わり方を示す言葉としては，豩木の“仕遂げて死な むと思ふ”よりマッカーサーの“消えゆくのみ”の方がずっ と受け入れやすい.

\section{5 大きな誤解：年寄りの活用法}

会合で，若い礼儀正しい司会者などが年寄りに何かの発言 
を求める時，「大所高所からのご意見を」というようなおだ て方をすることがよくある. 若い人は年寄りは大局的見地を 持っているはずと思い込んでいるふしがある。これは大きな 誤解である。

知って扔いて欲しいことは, 年寄りは年をとるほど枝葉末 節が気になるということである.だから, 論文原稿の校正で ミスを見つけるのはうまいが，序論と結論との整合が取れて いないことに気がつかなかったりする. 老眼になると, 肉体 的視野も, 精神的視野もともに狭くなる. 年寄りの大所高所 的意見など, 実は手前味噌にすぎず，あまり参考にしない方
がよい.むしろ, 年寄りの枝葉末節へのこだわりの方が珍重 に值する．それが先に述べたコツというものである.ガラス 基板上極薄膜の蒸着面判定法, ガラス管の曲げ方, 真空フラ ンジのボルトの締め方等々, 本でもインターネットでも見つ けにくいことを知っているのが年寄りである. 年寄りの自画 自賛を我慢すれば，彼らの枝葉末節談義こそが面白い。それ らをただ集めればがらくたの山かもしれないが，うまく選別 して整理すれば宝の山にもなりうる. 日本真空学会がこの真 空・薄膜技術に関する宝の山を作る役割を果たすことにかす かな期待を持つ。（おわり） 